\title{
SISTEM PEMBELAJARAN DI PONDOK PESANTREN AL-AZIZIYAH ANALISIS TERAPAN METODE DALAM KEGIATAN PEMBELAJARAN FORMAL DAN NON FORMAL
}

\author{
Mahmud \\ Mahmudizzaty@gmail.com
}

\begin{abstract}
Abstrak. Diakui bersama pada awal berdirinya pondok pesantren yang diakui bahwa dalam pembelajaran menggunakan pendekatan holistik dimana para pengasuh pesantren memandang bahwa kegiatan pembelajaran merupakan kesatupaduan dalam totalitas kegiatan hidup sehari-hari, sehingga bagi warga komunitas pondok pesantren belajar tidak mengenal perhitungan waktu, kapan harus dimulai dan harus selesai, dan target apa yang harus dicapai. Dalam kegiatan pembelajaran mereka sama mengaku bahwa ilmu agma fardu ain dipandang sakral sedangkan ilmu umum fardu kifayah tidak sakral. Dalam perkembangannya sejumlah sejumlah metode dapat diterapkan oleh guru atau ustadz/ustadzah dalam kegiatan pembelajaran antaranya (1) metode ceramah, (2) metode tanya jawab, (3) metode demonstrasi, (4) metode eksprimen, (5) metode diskusi, (6) metode sosiodrama dan bermain peran, (7) metode drill (latihan), (8) metode tim teaching (mengajar beregu), (9) metode problem solving (pemecahan masalah), (10) metode resitasi (pemberian tugas), (11) metode kerja kelompok, dan (12) metode simulasi. Demikian juga ketika pembelajaran Bahasa Arab yaitu (1) metode muhadasah (bercakap-cakap), (2) metode muthala'ah (membaca), (3) metode imla' (dekte), (4) metode insya' (mengarang), (5) metode mahfudzat (menghafal), dan (6) metode qawaid (nahu saref). Juga dalam kajian kitab kuning pada pembelajaran nonformal adalah (1) metode sorogan, (2) metode bandongan, dan (3) metode wetonan, dalam upaya pemahaman keilmuan baik ilmu umum terlebih ilmu agama (Ilmu Fikih, Qur'an-Hadis, Aqidah-Akhlak, SKI, dan kitab-kitab klasik/kitab kuning) kepada para santri. Tuntutan kemampuan dan keterampilan guru dalam menerapkan metode yang relevan dengan tujuan menjadi suatu keharusan baik di kelas non formal terebih di kelas formal. Adanya perbedaan penerapan jenis metode pembelajaran disebabkan karena tujuan pembelajaran yang berbeda, sehingga ketika guru memberikan pemahaman/kognitif tentunya jenis metodenyapun sesuai dengan tujuan tersebut, demikian juga ketika tujuan mengarah pada ranah afektif dan psikomotorik demikian juga adanya. Ini berarti tuntutan untuk mengetahui jenis-jenis metode dan keterampilan dalam terpannya secara terpadu menjadi suatu keharusan, yang keberhasilannya diperoleh melalui penerapan jenis alat evaluasi yang juga searah dengan tujuan pembelajaran yang dicapai. Dalam kenyataannya tuntutan tersebut dikalangan guru di Pondok Pesantren Al-Aziziyah belum terpenuhi meskipun secara akademis tingkat pendidikan mereka sebagaianbesar S.1 dan bahkan ada yang S.2. Guru yang memiliki jenjang pendidikan S.2 adalah 15 orang dari 213 guru atau 7,04\%, jenjang pendidikan S.1 160 orang atau 75,12 \%, jenjang Diploma 2 orang atau 0,94 \%, dan jenjang pendidikan SMA/MA 36 orang atau $16,9 \%$.
\end{abstract}

Kata Kunci: Metode, pembelajaran, kelas formal dan nonformal, Ponpes Al-Aziziyah

\section{Latar Belakang Masalah}

Kesadaran masyarakat akan pentingnya pendidikan bagi pemenuhan kebutuhan pengetahuan dan pembinaan sikap serta keterampilan dalam berbagai aspek kehidupan menjadi landasan pijakan berpikir tokoh-tokoh masyarakat dalam mempersiapkan lembaga-lembaga pendidikan untuk memenuhi kebutuh an tersebut di samping konsep secara nasional dan bahkan internasional dalam rangka membantu pemerintah mencerdasakan kehidupan bangsa agar dapat sejajar dalam kehidupan masyarakat internasional.

Paradigma berfikir tokoh masyarakat yang bertujuan membantu pemerintah menjejajarkan kehidupan masyarakat dalam konteks berbangsa dan bernegara sehingga 
dapat disandingkan dalam kehidupan internasional atau setara dengan kehidupan dan tingkat berpikir di negara lain diwujudkan dalam bentuk nyata dengan didirikannya lembaga-lembaga pendidikan Islam atau madrasah yang bernaung di bawah yayasan atau pondok pesantren dengan sistem pembelajaran formal dan non forml.

Diakui bersama pada awalnya pondok pesantren khususnya dalam konteks pembelajaran menggunakan pendekatan holistik dimana "para pengasuh pesantren memandang bahwa kegiatan belajar-mengajar (baca pembelajaran) merupakan kesatupaduan atau lebur dalam totalitas kegiatan hidup sehari-hari, sehingga bagi warga pesantren belajar tidak mengenal perhitungan waktu, kapan harus dimulai dan harus selesai, dan target apa yang harus dicapai. Warga pesantren sama mengaku bahwa ilmu agma fardu ain dipandang sakral sedangkan ilmu umum fardu kifayah tidak sakral "

Mencermati sarana pendukung pelaksanaan pembelajaran di awal berdirinya pondok pesantren masih sangat-sangat terbatas, sebab sarana pembelajaran yang digunakan dalam kegiatan pembelajaran kitab kuning hanya memanfaatkan masjid dan rumah kyai, ini sesuai dengan elemen dari pondok pesantren itu sendiri adalah "kyai, pondok, santri, masjid, pembelajaran kitab kuning”. Pembelajaran kitab kuning atau kitab-kitab wajib (Kutubul Muqarrarah) di pondok pesantren dimaksudkan agar para santri benar-benar ahli dalam bidang agama dan ilmu pengetahuan kemasyarakat serta berakhlak mulia, ini sesuai dengan tujuan pesantren sebagai lembaga pendidikan Islam yaitu "menjadikan para santri sebagai manusia yang mandiri yang diharapkan dapat menjadi pemimpin umat dalam menuju keridlaan Tuhan".

Dalam perkembangannya pondok pesantren tidak sebatas menjalankan pendidikan non formal yang berpusat di masjid, melainkan juga menerapkan sistem pembelajaran formal di madrasah, ini tentunya sesuai dengan empat dasar bagi para kyai (baca tuan guru) dalam pengabdiannya pada masyarakat yaitu "kyai sebagai pengabdi di masjid, kyai sebagai pengabdi di madrasah, kyai sebagai pengabdi di pesantren, dan kiyai sebagai pengabdi di sekolah"

Dengan diterapkannya pembelajaran di madrasah atau sekolah, maka pola pembelajaran di pondok pesantren selain pembelajaran yang bersifat non formal dengan sejumlah kitab-kitab kuning yang diajarkan di dalamnya serta jenis-jenis metode yang diterapkan, juga melalukan pembelajaran formal di kelas dengan tuntutan penerapan metode pembelajaran yang bervariasi dalam upaya mencapai tujuan pembelajaran Pendidikan Agama Islam sesuai materi yang diajarkan oleh masing-masing guru berdasarkan mata pelajaran yang diampunya.

Sejumlah metode dapat diterapkan dalam pembelajaran dalam Pendidikan Agama Islam (Fikih, Aqidah-Akhlak, alQur'an-Hadis, Sejarah Kebudayaan Islam dan termasuk Bahasa Arab), di sekolah/madrasah antaranya "(1) metode ceramah, (2) metode tanya jawab, (3) metode demonstrasi, (4) metode eksprimen, (5) metode diskusi, (6) metode sosiodrama dan bermain peran, (7) metode drill (latihan), (8) metode tim teaching (mengajar beregu), (9) metode problem solving (pemecahan masalah), (10) metode resitasi (pemberian tugas), (11) metode kerja kelompok, (12) metode imla' (dekte), dan metode simulasi”. Demikian juga ketika pembelajaran Bahasa Arab antaranya "(1) metode muhadasah (bercakap-cakap), (2) metode muthala'ah (membaca), (3) metode imla' (dekte), (4) metode insya' (mengarang), (5) metode mahfudzat (menghafal), dan (6) metode qawaid (nahu saref)".

Memperhatikan kitab-kitab kajian yang diajarkan pada pondok pesantren dengan sistem pembelajaran nonformal yang disertakan terapan sejumlah metode, serta juga pada pembelajaran di madrasah dan atau sekolah dengan tuntutan keterampilan ustadz/guru untuk melalukan terapan metode yang bervariasi berdasarkan jenis-jenis metode yang dapat diterapkan dan sesuai dengan tujuan pembelajaran pada pembelajaran Pendidikan Agama Islam termasuk pembelajaran Bahasa Arab sebagaimana dikemukakan di atas, jika kemudian dihubungkan dengan keberadaan 
pondok pesanstren dewasa ini (Tahun 2016) ketika penelitian ini dilakukan khususnya pada Pondok Pesantren Al-Aziziyah Kapek Gunungsari Lombok Barat yang keberadaannya sangat-sangat dikenal tidak sebatas dalam taraf regional namun juga nasional, menyebabkan termotivasinya peneliti untuk ingin mengetahui lebih dekat penerapan metode pembelajaran di Pondok Pesantren Al-Aziziyah Kapek Gunungsari Lombok Barat.

Motivasi peneleiti ini diperkuat dengan data hasil obervasi awal yang menunjukkan masih kurang bervariasinya penerapan metode berdasarkan tujuan pembelajaran sesuai ranah Bloom (ranah kognitif/pengetahuan/ilmu, ranah afektif/ sikap/iman, dan ranah psikomotor/keterampilan/amal) sesuai konten pembelajaran di Pondok Pesantren AlAziziyah oleh guru-guru bidang studi atau mata pelajaran baik pada pembelajaran formal khususnya pada Madrasah Tsnawiyah PutraPutri, Madrasah Aliyah Putra-Putri, dan pembelajaran di Madrasah Qur'an wal Hadis. Demikian pula penerapan metode pada pembelajaran non formal dalam mengkaji kitab kuning pada kegiatan ta'limul lail.

Sementara jika memperhatikan keberadaan ustadz/ustadzah atau guru yang mengajar di Pondok Pesantren Al-Aziziyah baik pada pembelajaran formal di Madrasah Tsnawiyah Putra-Putri, Madrasah Aliyah Putra-Putri, dan Madrasah Qur'an wal Hadis serta pada pembelajaran non formal (kajian kitab kuning) berjumlah 213 orang yang memiliki jenjang pendidikan S.2 15 orang atau 7,04 \%, yang memiliki jenjang pendidikan S.1 160 orang atau 75,12\%, yang memiliki jenjang pendidikan diploma 2 orang atau $0,94 \%$, dan yang memiliki jenjang pendidikan Sekolah Menengah Atas/Madrasah Aliyah 36 orang atau 16,9\%.

\section{Rumusan Masalah}

Berdasarkan latar belakang di atas yang diasumsi terjadi perbedaan antara pernyataan teori dengan kondisi nyata, maka dapat dirumuskan beberapa masalah sebagai berikut :

1. Metode-metode apakah yang diterapkan pada pembelajaran formal dan non formal di Pondok Pesantren Al-Aziziyah Kapek Gunungsari Lombok Barat?;

2. Bagaimanakah langkah penerapan metodemetode pada pembelajaran formal dan non formal di Pondok Pesantren Al-Aziziyah Kapek Gunungsari Lombok Barat?;

3. Faktor-faktor apakah yang mendukung dan menghambat penerapan metode-metode pada pembelajaran formal dan non formal di Pondok Pesantren Al-Aziziyah Kapek Gunungsari Lombok Barat dan langkah antisipatif dalam mengatasi faktor penghambatnya?;

\section{Tujuan Penelitian}

Berdasarkan rumusan masalah di atas, maka dapat dirumuskan tujuan penelitian yaitu untuk mengetahui :

1. Metode-Metode yang diterapkan pada pembelajaran formal dan non formal di Pondok Pesantren Al-Aziziyah Kapek Gunungsari Lombok Barat.

2. Langkah penerapan metode pada pembelajaran formal dan non formal di Pondok Pesantren Al-Aziziyah Kapek Gunungsari Lombok Barat.

3. Faktor-faktor yang mendukung dan menghambat penerapan metode pada pembelajaran formal dan non formal di Pondok Pesantren Al-Aziziyah Kapek Gunungsari Lombok Barat dan langkah antisipatif dalam mengatasi faktor penghambatnya.

\section{LANDASAN TEORI}

\section{Metode Pembelajaran di Pondok Pesantren}

Penerapan salah satu jenis metode dalam kegiatan pembelajaran hendaknya sesuai dengan tujuan dan materi yang diajarkan untuk kemudian diterapkan jenis alat evaluasi untuk mengetahui tingkat keberhasilan guru dalam mengajar dan keberhasilan siswa dalam belajar. Hal ini mengingat pembelajaran pada dasarnya adalah "rangkaian kegiatan yang direncanakan lebih dahulu oleh penyelenggara pendidikan atau oleh pengajar dan terarah pada hasil belajar tertentu". Atau pembelajaran adalah "suatu kombinasi yang tersusun, meliputi unsur-unsur manusiawi, material, fasilitas, perlengkapan, dan prosedur yang saling mempengaruhi untuk mencapai 
tujuan pembelajaran". Pembelajaran juga diartikan "setiap kegiatan yang dirancang untuk membantu seseorang mempelajari suatu kemampuan dan atau nilai yang baru". Bahkan pembelajaran atau proses belajar mengajar juga diartikan "serangkaian aktivitas yang disepakati dan dilakukan guru-murid untuk mencapai tujuan pendidikan secara optimal".

Memperhatikan

pengertian pembelajaran atau proses belajar mengajar di atas dapat ditemukan kata kunci yang terdapat di dalamnya dimana pembelajaran adalah kegiatan yang direncanakan oleh guru atau pengajar untuk mencapai tujuan pembelajaran. Pembelajaran sebagai kegiatan yang secara sengaja direncanakan oleh guru ketika berinteraksi dengan siswa dalam upaya mencapai tujuan pembelajaran itu sendiri dalam terapannya melalukan serangkaian komponen pembeljaran yang saling mendukung satu sama lain, salah satunya adalah komponen metode pembelajaran yang merupakan "cara yang digunakan oleh pendidik dalam mengadakan hubungan dengan peserta didik pada saat berlangsungnya proses pembelajaran".

Keberadaan metode pada kegiatan pembelajaran dapat diterapkan di kelas non formal (asrama, masjid, langgar dan sejenisnya) dan dapat pula diterapkan di kelas formal (sekolah atau madrasah) dimana pada pembelajaran non formal beberapa metode yang diterapkan antaranya :

1) Metode Wetonan atau Bandongan yang terapannya dilakukan dengan cara "kyai membaca sesuatu kitab dalam waktu tertentu dan santri membawa kitab yang sama, kemudian santri mendengarkan dan menyimak tentang bacaan kyai tersebut". Santri ketika ustadz/ ustadzah atau guru menerapkan metode ini diberikan kebebasan untuk mengikuti atau tidak mengikuti pembelajaran. Absensi santri tidak dilakukan ketika pembelajaran berlangsung dan tidak menggunakan istilah kenaikan kelas. Lama belajar santri tidak tergantung pada lama tahun belajar, akan tetapi ditentukan oleh cepat tidaknya santri manamatkan kitabnya. Bagi santri yang lebih cepat menamatkan kitabnya, maka yang bersangkutan boleh meneruskan ke kitab yang lebih tinggi atau mempelajari kitab yang lain.

2) Metode Sorogan, yang diakui merupakan "metode yang paling sulit dari keseluruhan metode pendidikan Islam tradisional, sebab dalam penerapan metode sorogan dituntut kesabaran, kerajinan, kataatan dan disiplin pribadi dari murid". Metode ini dalam penerapannya dilakukan dengan cara santri mengajukan kitab yang akan dibaca kepada kyai, kemudian ketika santri membaca kitab terdapat kesalahan, maka kesalahan tersebut disempurnakan langsung oleh kyai. Pembelajaran kitab dengan penerapan metode sorogan dilakukan untuk santri yang permulaan belajar atau kepada santrisantri khusus yang dianggap pandai dan diharapkan dikemudian hari menjadi seorang 'alim.

3) Metode Muhawarah atau muhadasah, merupakan metode untuk "melatih santri bercakap-cakap dengan bahasa Arab yang diwajibkan oleh pesantren kepada para santri selama mereka tinggal di pondok". Penerapan metode muhawarah atau muhadasah dibeberapa pesantren tidak diwajibkan dilakukan setiap hari, ada menerapkan satu atau dua kali dalam seminggu yang digabungkan dengan latihan muhadlarah atau kitabah yang bertujuan melatih ketrampilan santri berpidato.

4) Metode mudzakarah merupakan "suatu pertemuan ilmiah yang secara spesifik membahas masalah diniyah seperti ibadah dan akidah serta masalah agama pada umumnya". Dalam penerapannya metode mudzakarah dibedakan menjadi menjadi tiga tingkatan kegiatan, yaitu tingkatan pertama mudzakarah yang dilakukan oleh sesama santri untuk membahas suatu masalah dengan tujuan melatih para santri agar terlatih dalam memecahkan persoalan dengan menggunakan kitab-kitab yang tersedia. Salah seorang santri ditunjuk sebagai juru biacara untuk menyampaikan kesimpulan dari masalah yang didiskusikan. Tingkatan kedua mudzakarah yang dipimpin oleh kyai, dimana pada tingkatan ini hasil mudzakarah para santri 
diajukan untuk dibahas dan dinilai oleh kyai. Biasanya dalam mudzakarh tingkat kedua ini berisi tanya jawab dengan mayoritas menggunakan bahasa Arab sebagai bahasa komunikasi. Tingkat ketiga mudzakarah antar kyai. Ini biasanya menggunakan kitab-kitab yang tersedia untuk menyelesaikan suatu masalah yang penting. Mudzakarah ini juga dilakukan untuk memper dalam pengetahuan agama para kyai, dan

5) Metode majlis ta'lim merupakan "suatu media penyampaian ajaran Islam yang bersifat umum dan terbuka". Dalam penerapan metode ini peserta pembelajaran atau disebut dengan jama'ah terdiri dari berbagai lapisan yang memiliki latar belakang pengetahuan bermacam-macam dan tidak dibatasi oleh tingkat usia maupun perbedaan kelamin. Penerapan metode pada kegiatan ta'lim di pondok pesantren dilakukan pada waktu-waktu tertentu, ada yang seminggu sekali atau sebulan sekali. Terkait dengan materi yang disampaikan dengan penerapan metode ini "umumnya berisi nasehat-nasehat keagamaan yang bersifat amar ma'ruf nahi munkar. Ada kalanya materi diambil dari kitab-kitab tertentu seperti tafsir Qur'an dan Hadits".

Sedangkan pada pembelajaran formal (di sekolah atau madrasah) di antara metode yang dapat diterapkan yaitu :

1) Metode ceramah merupakan "cara penyajian atau penyampaian informasi melalui penerangan dan penuturan secara lisan oleh pendidik terhadap peserta didiknya". Jika mencermati ayat-ayat alQur'an yang disampaikan kepada Nabi Muhammad saw. ternyata banyak disampaikan dalam bentuk ceramah. Salah satunya adalah firman Allah swt. dalam surat Yunus ayat 23 :

"Dan perempuan yang dia (Yusuf) tinggal di rumahnya menggoda dirinya. Dan dia menutup pintu-pintu, lalu berkata "Marilah, mendekat kepadaku”. Yusuf berkata "Aku berlindung kepada Allah, sungguh, tuanku telah memperlakukan aku dengan baik". Sesungguhnya orang yang zalim itu tidak akan beruntung" (Q.S. Yusuf : 23).
Metode ini akan dapat diterapkan dalam kegiatan pembelajaran oleh ustadz/ustadzah atau guru jika (1) jumlah peserta didik terlampau banyak sehingga sulit menyampai kan metode lain, (2) bahan yang disampaikan merupakan topik baru yang mengandung informasi, penjelasan atau uraian (3) tidak ditemui bahan yang disampaikan itu dalam buku yang akan dipergunakan oleh peserta didik sebagai buku pedoman (4) pendidik seorang pembicara yang mahir dan bersemangat dan dapat menarik serta merangsang perhatian peserta didik (5) pendidik menyimpulkan dari pokok-pokok yang penting dari ceramah yang diberikan, sehingga peserta didik-peserta didik dapat melihat hubungan antara pokok-pokok masalah itu, (6) bahan yang hatus diajarkan banyak sekali sedangkan waktu amat terbatas, (7) dalam memberikan gambaran/ilistrasi terhadap bahan pelajaran dan kata-kata tertentu, metode ceramah yang tepat dipergunakan, (8) untuk menumbuhkan serta menanamkan apresiasi/penghayatan terhadap isi sajak, puisi, watak orang, dengan metode ceramah juga dapat dilaksanakan, dan (9) apabila tidak ada alat-alat yang lain kecuali bahasa lisan.

Dalam terapannya metode ini memiliki kelebihan di samping kekuarangan dimana kelebihanya adalah (1) suasana kelas berjalan dengan tenang karena peserta didik melakukan aktifitas yang sama, sehingga pendidik dapat mengawasi peserta didik sekaligus, (2) tidak membutuhkan tenaga yang banyak dan waktu yang lama, dengan waktu yang sedikit peserta didik dapat menerima pelajaran sekaligus, (3) pelajaran bisa dilaksanakan dengan cepat, karena dalam waktu yang sedikit dapat diuraikan bahan yang banyak, dan (4) pleksibel dalam penggunaan waktu dan bahan, jika bahan banyak sedangkan waktu terbatas dapat dibicarakan pokok-pokok permasalahannya saja, sedangkan bila materi sedikit sedangkan waktu masih panjang, dapat dijelaskan lebih mendetail. Kekurangannya (1) interaksi cenderung bersifat teacher centered (berpusat pada pendidik), (2) pendidik kurang dapat mengetahui dengan pasti sejauhmana peserta didik telah menguasai bahan ceramah (3) pada 
peserta didik dapat terbentuk konsep-konsep yang lain dari apa yang dimaksudkan pendidik, (4) sering sukar ditangkap kamsudnya, bila ceramah berisi istilah-istilah yang tidak/kurang dimengerti peserta didik sehingga mengarah kepada verbalisme (5) tidak memberi kesempatan kepada peserta didik untuk memecahkan masalah, dan berpikir. Karena peserta didik diarahkan untuk mengikuti pikiran pendidik, (6) kurang memberi kesempatan kepada peserta didik untuk mengembangkan kecakapan untuk mengeluarkan pendapat sendiri, (7) bilamana pendidik menyampaikan bahan sebanyakbanyaknya dalam tempo yang terbatas, menimbulkan kesan pemompaan atau pemaksaan terhadap kemampuan penerimaan peserta didik, dan (8) cenderung membosankan dan perhatian peserta didik ber kurang, karena pendidik kurang memperhatikan faktor-faktor psikologis peserta didik, sehingga bahan yang dijelaskan menjadi kabur di hati mereka.

Kelemahan yang terdapat dialam metode ceramah dapat di atasi, bila guru dalam pembelajaran memperhatikan (1) untuk menghilangkan kesalahpahaman bagi peserta didik terhadap materi yang diberikan, diberi penjelasan dengan mem berikan keteranganketerangan, dengan gerak-gerik, dengan memberikan contoh atau dengan memakaikan alat peraga, (2) selinglah metode ceramah dengan metode yang lain untuk menghilangkan keboasan anak-anak, (3) susunlah ceramah itu secara sistematis, (4) dalam menerangkan pelajaran hendaknya digunakan kata-kata yang sederhana, jelas, dan mudah dipahami oleh para peserta didik, (5) gunakan alat visualisasi, seperti penggunaan papan tulis atau media lainnya yang tersedia untuk menjelaskan pokok bahasan yang disampaikan, dan (6) adakah rekapitulasi dan ulang kembali rumusanrumusan yang dianggap penting.

2) Metode tanya jawab adalah "suatu cara menyajikan materi pelajaran dengan jalan guru mengajukan suatu pertanyaanpertanyaan kepada siswa untuk dijawab, bisa pula diatur pertanyaan-pertanyaan diajukan oleh siswa lainnya". Penerapan metode ini dalam al-Qur'an banyak dicontohhkan oleh Allah swt. dalam menyampaikan firman-Nya, diantaranya dalam surat Ar-Rahman ayat 46-51, sebagai berikut :

(46) Dan bagi siapa yang takut akan saat menghadap Tuhannya ada dua syurga (surga untuk manusia dan surga untuk jin, dan ada juga mufassir yang berpendapat surga dunia dan surga akhirat), (47) maka nikmat Tuhanmu yang manakah yang kamu dustakan?, (48) kedua syurga itu mempunyai aneka pepohonan dan buah-buahan, (49) maka nikmat Tuhanmu yang manakah yang kamu dustakan?, (50) Di dalam kedua syurga itu ada dua buah mata air yang memancar, (51) maka nikmat Tuhanmu yang manakah yang kamu dustakan?.

Metode ini dapat diterapkan bila : (a) guru atau ustadz bermaksud mengetahui penguasaan materi pelajaran yang telah dipelajari, baik dari pelajaran yang lalu untuk meneruskan pelajaran berikutnya (yang baru), maupun yang sudah ditugaskan untuk dipelajari (b) guru atau ustadz bermaksud menarik dan memusatkan perhatian murid atau santri dalam mengikuti ceramahnya tentang suatu materi pelajaran tertentu, (c) untuk melakukan pengecekan perhatian murid atau santri pada waktu mendengarkan ceramah, mengenai suatu materi pelajaran dari guru atau ustadz, dan (d) guru atau ustadz bermaksud mengarahkan atau memimpin pemikiran atau pengamatan murid atau santri.

Kelebihan metode tanya jawab adalah (1) dapat mengaktifkan murid (santri) dalam belajar, sehingga tidak sekedar diam dan mendengarkan saja. Dengan demikian suasana kelas menjadi hidup dan dinamis, (2) dapat mengurangi verbalisme dan memberi peluang kepada murid (santri) untuk menanyakan sesuatu yang kurang jelas atau belum dipahaminya, dan (3) metode ini merupakan awal dari diskusi. Dengan menggunakan metode ini berarti murid (santri) berkesempatan melatih diri dalam menyusun pertanyaan, di samping itu berlatih juga dalam merumuskan jawaban. Kelemahannya (1) pemakaian waktu lebih banyak jika dibandingkan dengan metode ceramah, (2) mungkin terjadi perbedaan pendapat antara pendidik dan peserta didik, 
sehingga baik pendidik dan peserta didik harus dapat membuktikan kebenaran jawabanjawabannya, (3) sering terjadi penyeleweng an dari masalah pokok, disebabkan pertanyaan terlalu sulit dan kurang dipahami oleh peserta didik, sehingga perlu diusahakan agar perhatian siswa tertuju kepada masalah semula, dan (4) apabila peserta didik terlalu banyak tidak cukup waktu memberi giliran kepada setiap peserta didik.

4. Metode demontrasi merupakan "cara yang digunakan dalam penyajian pelajaran dengan cara meragakan bagaimana membuat, mempergunakan serta memperaktikkan suatu benda atau alat baik asli maupun tiruan, atau bagaimana mengerjakan sesuatu perbuatan atau tindakan yang mana dalam meragakan disertai dengan penjelasan lisan".

Metode ini banyak dicontohkan oleh Rasulullah saw. ketika memberi kan penjelasan tentang tatacara dalam melakukan suatu kewajiban seperti tatacara berwudu', salat, haji dan sebagainya, dimana Rasulullah saw, memberikan contoh cara melakukannya yang kemudian diikuti oleh umatnya. Dinyatakan dalam salah satu hadis Rasulullah saw. terkait dengan pelaksanaan wudu' :

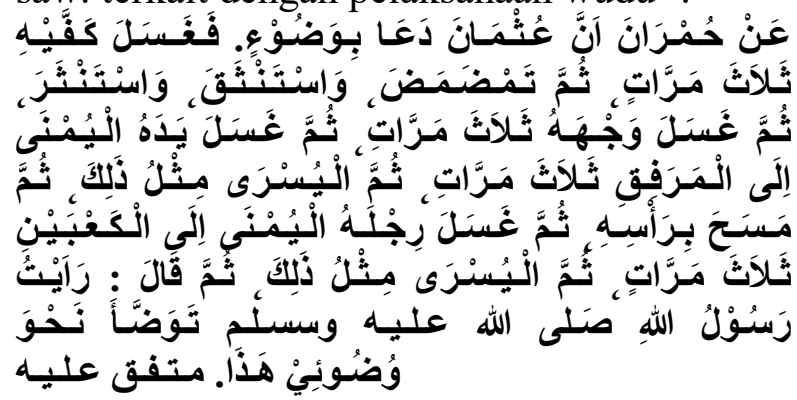

"Dari Humran, bahwasanya 'Utsman minta air wudlu', lalu ia cuci dua tangannya tiga kali, kemudian ia berkumur-kumur dan menaikkan air ke hidung dan menghembuskannya, kemudian ia cuci mukanya tiga kali, kemudian ia cuci tangannya yang kanan sampai siku tiga kali, kemudian yang kiri seperti demikian, kemudian ia usap kepalanya, kemudian ia cuci kakinya yang kanan sampai mata kaki tiga kali, kemudian yang kiri seperti demikian, kemudian ia berkata : Saya pernah lihat Rasulullah saw. Berwudlu' seperti wudlu' saya ini. (H.R. Muttafaq 'alaih)”.
Kelebihan metode ini adalah (1) keaktifan peserta didik akan ber tambah, lebih-lebih kalau peserta didik diikut sertakan, (2) pengalaman peserta didik bertambah karena peserta didik turut membantu pelaksanaan suatu demontrasi sehingga ia menerima pengalaman yang bisa mengembang kan kecakapannya (3) pelajaran yang diberikan lebih tahan lama, karena dalam suatu demontrasi peserta didik bukan saja mendengar suatu uraian yang diberikan oleh pendidik tetapi juga memperhatikannya bahkan turut serta dalam pelaksanaan suatu demontrasi, (4) pengertian lebih cepat dicapai, karena peserta didik dalam menanggapi suatu proses adalah dengan menggunakan alat pendengar, penglihat, dan bahkan dengan perbuatannya sehingga memudahkan pemahaman peserta didik dan meng hilangkan sifat verbalisme dalam belajar, (5) perhatian peserta didik dapat dipusatkan dan titik yang dianggap penting oleh pendidik dapat diamati oleh peserta didik seperlu nya, sebab peserta didik lebih banyak diajak mengamati proses yang sedang berlangsung dari pada hanya semata-mata mendengar saja, (6) mengurangi kesalahan-kesalahan paham yang diberikan melalui penjelasan lisan, sebab melalui demontrasi di samping peserta didik mendapatkan penjelasan dengan lisan juga dapat memberi kan gambaran konkrit, (7) beberapa masalah yang menimbulkan pertanyaan atau masalah dalam diri peserta didik dapat terjawab pada waktu peserta didik mengamati proses demontrasi, dan (8) menghindari "coba-coba dan gagal" yang banyak memakan waktu belajar, di samping praktis dan fungsional, khususnya bagi peserta didik yang ingin berusaha mengamati secara lengkap dan teliti atau jalannya sesuatu.

Kelemahannya (1) metode ini membutuhkan kemampuan yang optimal dari pendidik untuk itu perlu persiapan yang matang, dan (2) sulit dilaksanakan kalau tidak ditunjang oleh tempat, waktu dan peralatan yang cukup.

5. Metode drill (latihan) atau disebut juga dengan latihan sikap, merupa kan "cara menyajikan bahan pelajaran dengan jalan/cara melatih siswa agar menguasai 
pelajaran dan terampil dalam melaksanakan tugas latihan yang diberikan".

Dalam Al-Qur'an metode ini banyak dicontohkan dalam bentuk terapannya antaranya sebagaimana dinyatakan Allah swt. dalam surat al-Hijir ayat 87 :

"Dan sungguh, Kami telah berikan kepadamu tujuh (ayat) yang (dibaca) berulang-ulang (surat al-Fatihah yang terdiri dari tujuh ayat, sebagian mufassir mengatakan tujuh surah yang panjang, yaitu al-Baqarah, 'Ali Imran, al-Maidah, an-Nisa', al-'A'raf, al-'An'am, dan al-Anfal atau atTaubah) dan Al Quran yang agung” (Q.S. AjHijir : 87).

Kelebihannya (1) dalam waktu yang tidak terlalu lama siswa dapat memperoleh pengetahuan dan keterampilan yang diperlukan, (2) siswa memperoleh pengetahuan praktis dan siap pakai, mahir dan lanca,(3) menumbuhkan kebiasaan belajar secara kontinu dan disiplin diri, melatih diri, belajar mandiri (4) Pada pelajaran agama dengan melalui metode latihan siap ini anak didik menjadi terbiasa dan menumbuhkan semangat untuk beramal kepada Allah.

Kekurangannya (1) dapat menjadi penghambat bakat dan inisiatif siswa sebab melalui cara/metode ini, berarti para siswa dibawa kepada konformitas dan diarahkan kepada uniformitas, (2) siswa dapat statis dalam penyesuaian dengan situasi lingkungan dan terpaku dengan petunjuk-petunjuk praktis tertentu, serta inisiatif siswa untuk mengembangkan sesuatu yang baru menjadi terikat. Hal ini berarti bertentangan dengan prinsip-prinsip teori belajar, (3) membentuk kebiasaan yang kaku yang bersifat mekanis dan rutinitas. Kurang memperhatikan aspek intelektual anak didik, (4) pengajaran cenderung bersifat verbalisme, (5) dalam melaksanakan metode ini memakan waktu/proses yang cukup banyak/lama (6) dalam pelajaran agama memerlukan ketelatenan/ketekunan serta kesabaran dari pihak guru maupun dari siswa sendiri.

6. Metode probel solving (pemecahan masalah) adalah "penyajian bahan ajar oleh guru dengan merangsang anak berpikir secara sistematis dengan menghadapkan siswa kepada beberapa masalah yang harus dipecahkan".

Metode ini memilii sisi positif, yaitu (1) memungkinkan relevansi antara dunia pendidikan dengan dunia kerja, (2) membiasakan siswa terampil menghadapi dan memecahkan masalah (3) merangsang proses berfikir kreatif dan menyeluruh. Sisi negatifnya (1) sulit menentukan tingkat masalah yang disesuaikan dengan tingkat pemahaman dan perkembangan siswa, (2) memakan waktu yang lama dan menyita waktu yang diperguna kan untuk jam pelajaran lain, (3) sulit mengubah pola belajar siswa dari menjadikan guru sebagai sumber belajar utama kepada belajar dengan berpikir yang mem butuhkan lebih banyak lagi sumber belajar.

7. Metode resitasi (pemberian tugas) merupakan "cara mengajar di mana seorang pendidik memberikan tugas-tugas tertentu kepada peserta didik, sedangkan hasil tersebut diperiksa oleh pendidik dan peserta didik mempertanggung jawabkannya".

Terkait dengan terapan metode ini Allah mencontohkan di dalam Al-Qur'an surat at-Taubah ayat 105 :

"Dan katakanlah,"Bekerjalah kamu, maka Allah akan melihat pekerjaanmu, begitu juga Rasul-Nya serta orang-orang mukmin, dan kamu akan dikembalikan kepada (Allah) Yang Mengetahui akan yang ghaib dan yang nyata, lalu diberitakan-Nya kepada kamu apa yang telah kamu kerjakan" (Q.S. at-Tabuah : 105).

Kelebihannya (1) peserta didik belajar membiasakan untuk mengambil inisitaif sendiri dalam segala tugas yang diberikan, (2) meringankan tugas pendidikan yang diberikan, (3) dapat mempertebal rasa tanggung jawab, karena hasil-hasil yang dikerjakan dipertanggung jawabkan dihadapan pendidik, (4) memupuk anak mereka dapat berdiri sendiri tanpa mengharap kan bantuan orang lain, (5) mendorong peserta didik supaya suka berlomba-lomba untuk mencapai sukses, (6) hasil pelajaran akan tahan lama karena pelajaran sesuai dengan minat peserta didik, (7) dapat memperdalam pengertian dan menambah keaktipan dan kecakapan peserta didik, (8) 
waktu yang dipergunakan tidak terbatas sampai pada jam-jam sekolah. Sedangkan kelemahannya (1) peserta didik yang terlalu bodoh sukar sekali belajar, (2) kemungkinan tugas yang diberikan tapi dikerjakan oleh orang lain, (3) kadang-kadang peserta didik menyalin atau meniru pekerjaan temannya sehingga pengalamannya sendiri tidak ada, (4) kadang-kadang pembahasan nya kurang sempurna, (5) bila tugas terlalu sering dilakukan oleh peserta didik akan menyebabkan (a) terganggunya kesehatan peserta didik, karena mereka kembali dari sekolah selalu melakukan tugas, sehingga waktu bermain tidak ada, (b) menyebabkan peserta didik asal mengerjakan saja karena mereka menganggap tugas-tugas tersebut membosankan, (6) mencari tugas yang sesuai dengan kemampuan setiap individu sulit, jalan pelajaran lambat dan memakan waktu yang lama, (7) kalau peserta didik terlalu banyak kadang-kadang pendidik tidak sanggup memeriksa tugas-tugas peserta didik tersebut

8. Metode diskusi adalah "metode pembelajaran yang menghadapkan siswa pada suatu permasalahan dengan tujuan untuk memecahkan suatu permasalahan, menjawab pertanyaan, menambah dan memahami pengetahuan siswa, serta untuk membuat suatu keputusan".

Jika mengkaji ayat-ayat al-Qur'an ditemukan ayat-ayat al-Qur'an dimana Allah swt. mengajukan pertanyaan kepada ummatnya untuk menemukan jawabannya melalui diskusi, sebagaimana yang tertuang dalam surat al-Alaq ayat 5-14 :

(5) Dia mengajar manusia apa yang tidak diketahuinya, (6) sekali-kali tidak! Sungguh manusia benar-benar melampaui batas, (7) apabila melihat dirinya serba cukup, (8) Sungguh, hanya kepada Tuhanmulah kembali(mu), (9) Bagaimana pendapatmu tentang orang yang melarang?, (10) seorang hamba ketika mengerjakan salat, (11) bagaimana pendapatmu jika dia (yang dilarang salat itu) berada di atas kebenaran (petunjuk), (12) atau dia menyuruh bertakwa (kepada Allah)?, (13) Bagaimana pendapatmu jika dia (yang melarang) itu mendustakan dan berpaling?, (14) Tidaklah dia mengetahui bahwa sesungguhnya Allah melihat (segala perbuatannya)?.

Kelebihannya (1) etode diskusi dapat merangsang siswa untuk lebih kreatif khususnya dalam memberikan gagasan dan ide-ide, (2) dapat melatih untuk membiasakan diri bertukar pikiran dalam mengatasi setiap permasalahan, (3) dapat melatih siswa untuk dapat mengemukakan pendapat atau gagasan secara verbal. Di samping juga bisa melatih siswa untuk menghargai pendapat orang lain.

Kelemahannya (1) sering terjadi pembicaraan dalam diskusi dikuasai oleh 2 atau 3 orang siswa yang memiliki keterampilan berbicara, (2) kadan-kadang pembahasan dalam diskusi meluas, sehingga kesimpulan menjadu kabur, (3) memerlukan waktu yang cukup panjang, yang kadangkadang tidak sesuai dengan cara yang direncanakan, (4) dalam diskusi sering terjadi perbedaan pendapat yang bersifat emosional yang tidak terkontrol, akibatnya kadangkadang ada pihak yang merasa tersinggung, sehingga dapat mengganggu iklim pembelajaran.

Bagi peneliti sejumlah jenis-jenis metode pembelajaran di atas, dapat dijadikan refrensi ketika mengkaji pengetahuan dan keterampilan ustadz/ustadzah atau guru dalam menerapkan setiap jenis metode dalam pembelajaran Pendidikan Agama Islam khususnya di Pondok Pesantren Al-Aziziyah Kapek Gunungsari Lombok Barat.

\section{METODE PENELITIAN}

\section{Pendekatan Penelitian}

Pendekatan yang digunakan peneliti dalam penelitian ini adalah pendekatan deskriptif kualitatif. Sebab orientasi penelitian yang dilakukan berdasarkan pada gejala atau fenomena yang bersifat alam. Sehingga hasil yang didapatkan adalah data deskriptif atau pemaparan dari suatu peristiwa yang diteliti. Metode penelitian kualitatif sebagai "prosedur penelitian yang menghasilkan data deskriptif berupa kata-kata tertulis atau lisan dari orangorang dan perilaku yang dapat diamati”. Pendekatan kualitatif diterapkan dalam kegiatan penelitian menurut Lexy J. Moleong, jika "Penelitian yang bermaksud untuk memahami fenomena tentang apa yang dialami oleh subjek penelitian misalnya 
perilaku, persepsi, motivasi, tindakan dll, secara holistik dan dengan cara deskripsi dalam bentuk kata-kata dan bahasa, pada suatu konteks khusus yang alamiah dan dengan memanfaatkan berbagai metode alamiah".

\section{Kehadiran Peneliti}

Dalam penelitian kualititatif kehadiran peneliti di lokasi penelitian adalah sebagai instrumen kunci dalam upaya menemukan data melalui pengamatan atau observasi secara langsung atau observasi partisipasi dan observasi nonpartisipasi. Peneliti sebagai instrmen kunci sesuai pernyataan bahwa "metode penelitian yang berdasarkan pada filsafat postpositivisme, digunakan untuk meneliti pada kondisi obyek yang alamiah dimana peneliti adalah sebagai instrument kunci...".

Dalam penelitian ini diterapkan metode observasi nonpartisipasi mengingat peneliti sebatas sebagai pengumpul data bukan sebagai pelaksana kegiatan dalam hal ini berperan sebagai guru mata Pelajaran Pendidikan Agama Islam (Fikih, AqidahAkhlak, Al-Qur'an-Hadis, Sejarah Kebudayaan Islam dan juga Bahasa Arab). Hasil data yang diperoleh melalui pengamatan tersebut didukung dengan hasil data melalui wawancara dan dokumentasi. Karena ketika peneliti berada di lokasi penelitian dalam upaya penemuan data sesuai fokus kajian yang terkait dengan sistem pembelajaran pada Pondok Pesantren Al-Aziziyah yang menekankan pada kajian jenis-jenis metode yang diterapkan dalam kegiatan pembelajaran formal dan non formal, diperlukan penerapan metode wawancara, metode observasi atau pengamatan dan metode dokumentasi.

\section{Lokasi Penelitian}

Penelitian dilakukan di Pondok Pesantren Al-Aziziyah Kapek Gunungsari Lombok Barat, yang berdasarkan observasi awal ditemukan data bahwa ustadz/ustadzah atau guru yang mengajar di pondok pesantren ini baik yang mengajar pada pembelajaran non formal dan juga pada pembelajaran formal khususnya terkait dengan bidang studi Pendidikan Agama Islam kurang kreatif dalam menerapkan jenis-jenis metode sesuai tujuan pembelajaran yang mengarah pada ranah Bloom (kognitif/ pengetahuan/ilmu, ranah afektif/sikap/iman, dan ranah psikomotorik/keterampilan/amal), yang hal ini kurang relefan dengan keberadaan Ustadz/ustadzah atau guru yang berjumlah 2013 jika dilihat dari jenjang pendidikannya yaitu S.2 15 orang atau 5,75 \%, yang memiliki jenjang pendidikan S.1 198 orang atau $75,86 \%$, yang memiliki jenjang pendidikan diploma 2 orang atau $0,77 \%$, dan yang memiliki jenjang pendidikan Sekolah Menengah Atas/Madrasah Aliyah 36 orang atau $13,79 \%$.

\section{Sumber Data}

Dalam penelitian kualitataif tidak menggunakan istilah populasi, tetapi oleh Spredley dalam Sugiono, dinamakan "tempat (place), pelaku (actor) dan aktivitas (actifity) yang berinteraksi secara sinergi. Situasi sosial tersebut, dapat di rumah berikut keluarga dan aktivitasnya, atau orang-orang disudut jalan yang sedang ngobrol, atau ditempat kerja, di kota, desa, di sekolah atau wilayah suatu negara".

Dalam melakukan penelitian, peneliti memilih informan yang dapat membantu untuk mendapatkan data yaitu: person atau orang adalah sumber data yaitu guru Pendidikan Agama Islam yang mengajar di Pondok Pesantren Al-Aziziyah Kapek Gunungsari Lombok Barat baik pada pembelajaran formal maupun non formal.

\section{Prosedur Pengumpulan Data}

Pengumpulan data pada penelitian ini menggunakan metode observasi, metode wawancara, dan metode dokumentasi. (a) metode bbservasi (pengamatan) yang dimaknai sebagai sebagai "pengamatan dan pencatatan secara sistematis terhadap gejala yang tampak pada objek penelitian", memiliki tiga jenis yaitu (1) observasi langsung, yaitu observasi yang dilakukan dimana observar berada bersama objek yang diselidiki, (2) observasi tidak langsung, yaitu observasi atau pengamatan ayng dilakukan tidak pada saat berlangsungnya peristiwa yang akan diteliti, misalnya dilakukan melalui film, rangkaian slide, atau rangkaian foto. Di samping jenis (1) observasi berperanserta (participant observation), yaitu peneliti terlibat dengan kegiatan sehari-hari orang yang sedang 
diamati atau yang digunakan sebagai sumber data penelitian. Sambil melakukan pengamatan, peneliti ikut melakukan apa yang dikerjakan oleh sumber data, dan ikut merasakan suka dukanya, dan (2) observasi nonpartisipasi, yaitu peneliti tidak terlibat langsung dengan aktivitas orang sedang diamati, tetapi hanya sebagai pengamat independen.

Dari jenis observasi di atas, dalam penelitian ini diterapkan metode observasi tidak langsung, untuk memperoleh data (1) jenis-jenis metode yang diterapkan pada pembelajaran formal dan non formal di Pondok Pesantren Al-Aziziyah Kapek Gunungsari Lombok Barat, (2) langkah penerapan metode-metode pada pembelajaran formal dan non formal di Pondok Pesantren Al-Aziziyah Kapek Gunungsari Lombok Barat, dan (3) faktor-faktor yang mendukung dan menghambat penerapan metode-metode pada pembelajaran formal dan non formal di Pondok Pesantren Al-Aziziyah Kapek Gunungsari Lombok Barat dan langkah antisipatif dalam mengatasi faktor penghambatnya, serta (4) letak geografis Pondok Pesantren Al-Aziziyah Kapek Gunungsari Lombok Barat.

(b) metode interview/wawancara yang diartikan sebagai "percakapan dengan maksud tertentu, percakapan itu dilakukan oleh dua pihak, yaitu pewawancara (interviewer) yang mengajukan pertanyaan dan terwawancara (interviewee) yang memberikan jawaban atas pertanyaan itu". Metode ini terdiri dari "(1) wawancara berstruktur, dimana pertanyaan dan alternatif jawaban yang diberikan kepada interviewee telah ditatapkan terlebih dahulu, (2) wawancara tak terstruktur lebih bersifat informal, pertanyaan-pertanyaan tentang pandangan hidup, sikap, keyakinan subjek, atau tantang keterangan lainnya dapat diajukan secara bebas pada subjek". Dalam penelitian ini peneliti menggunakan wawancara tak ter struktur yaitu pada saat melakukan wawancara tidak menetapkan terlebih dahulu pertanyaan-pertanyaan yang akan dipertanyakan, dengan tujuan untuk menyegarkan suasana dialog supaya tidak kaku, dan untuk pengembangan pertanyaanpertanyaan sesuai kebutuhan peneliti.
Data yang dikumpulkan dari metode ini adalah (1) jenis-jenis metode yang diterapkan pada pembelajaran formal dan non formal di Pondok Pesantren Al-Aziziyah Kapek Gunungsari Lombok Barat, (2) langkah penerapan metode-metode pada pembelajaran formal dan non formal di Pondok Pesantren Al-Aziziyah Kapek Gunungsari Lombok Barat, dan (3) faktor-faktor yang mendukung dan menghambat penerapan metode-metode pada pembelajaran formal dan non formal di Pondok Pesantren Al-Aziziyah Kapek Gunungsari Lombok Barat dan langkah antisipatif dalam mengatasi faktor penghambatnya, dengan sumber datanya Guru-guru Pendidikan Agama Islam (Fikih, Aqidah-Akhlak, Qur'an-Hadis, dan SKI), termasuk Guru Mata pelajaran Bahasa Arab pada jenjang pendidikan Tsnawiyah PutraPutri, Madrasah Aliyah Putra-Putri, dan Madrasah Qur'an wal Hadis, serta pada ta'limul lail pada kajian kitab.

(c) Metode dokumentasi merupakan "cara mencari data mengenai hal-hal atau variabel yang berupa catatan, transkrip, buku, surat kabar, majalah, prasasti, notulen rapat, lengger, agenda, dan sebagainya". Dokumen yang adalah (1) gambaran Umum Madrasah, dan (2) Keadaan Guru dan siswa khususnya pada Madrasah Tsnawiyah Putra-Putri, Madrasah Aliyah Putra-Putri dan Madrasah Qur'an wal Hadis Pondok Pesantren AlAziziyah Kapek Gunungsari Lombok Barat.

\section{Analisa Data}

Analisis data adalah "upaya yang dilakukan dengan jalan bekerja dengan data, mengorganisasikan data, memilah-milahnya menjadi satuan yang dapat dikelola, mensintesiskannya, mencari dan menemukan pola, menemukan apa yang penting dan apa yang dipelajari, dan memutuskan apa yang dapat diceritakan kepada orang lain", yang dalam penelitian menggunakan analisis induktif yaitu "suatu analisis berdasarkan data yang diperoleh, selanjutnya dikembangkan pola hubungan tertentu atau menjadi hipotesis".

Analisis data dengan jenis digunakan melalui proses mencatat hasil penelitian untuk mencari dan menemukan secara sistematis catatan observasi, wawancara, dan 
dokumentasi untuk meningkatkan pemahaman penelitian tentang masalah yang diteliti dan menyajikan suatu temuan bagi orang lain. Sedangkan yang ditempuh peneliti dalam menggunakan analisis data ini adalah (1) data Reduction (Reduksi Data) yang berarti merangkum, memilih hal-hal yang pokok, memfokuskan pada hal-hal yang penting, dicari tema dan pokoknya dan membuang yang tidak perlu. Dengan demikian data yang telah direduksi akan memberikan gambaran yang lebih jelas, dan mempermudah peneliti untuk melakukan pengumpulan data selanjutnya, dan mencarinya bila diperlukan, (2) data Display (Penyajian Data) yang bentuknya bisa uraian singkat, bagan, hubungan antar kategori dansejenisnya, (3) Conclusion Drawing atau Verification (Mengambil Kesimpulan dan Verifikasi), dimana kesimpulan awal yang dikemukakan masih bersifat sementara, dan akan berubah bila tidak ditemukan bukti-bukti yang kuat yang mendukung pada tahap pengumpulan data berikutnya. Tetapi apabila kesimpulan yang dikemukakan pada tahap awal, didukung oleh bukti-bukti yang valid dan konsisten saat peneliti kembali ke lapangan mengumpulkan data, maka kesimpulan yang kemukakan merupakan kesimpulan yang kredibel.

\section{Kredibilitas Data}

Kredibilitas data atau kepercayaan terhadap data hasil penelitian kualitatif antara lain dilakukan dengan perpanjangan keikutsertaan, peningkatan ketakunan dalam penelitian, triangulasi, diskusi dengan teman sejawat, analisis kasus negatif, dan member Check. Penelitian ini memanfaatkan keabsahan data (1) ketekunan atau Keajekan Pengamatan, yang berarti "mencari secara konsisten interpretasi dengan berbagai cara dengan proses analisis yang konstan dan tentatif". Ketekunan pengamatan bermaksud "menemukan ciri-ciri dan unsur-unsur dalam situasi yang sangat releven dengan persoalan atau isu yang sedang dicari dan kemudian memusatkan diri pada hal-hal tersebut secara rinci.

(2) Triagulasi, yang merupakan "teknik pemeriksaan keabsahan data yang memanfaatkan sesuatu yang lain”. Dari empat jenis trianggulasi yaitu "penggunaan sumber, metode, penyidik, dan teori", dalam penelitian ini menggunakan trianggulasi sumber di samping trianggulasi metode dan trianggulasi data.

\section{HASIL PENELITIAN}

Penelitian menghasilkan data berupa diterapkan empat metode dalam pembelajaran formal di Madrasah Tsnawiyah Putra-Putri, Madrasah Aliyah Putra-Putri, dan Madrasah Qur'an wal Hadis Pondok Pesantren AlAziziyah pada pembelajaran Pendidikan Agama Islam (Fikih, Aqidah-Akhlak, AlQur'an-Hadis dan juga Bahasa Arab) yaitu (a) metode ceramah, (b) metode tanya jawab, (c) metode penugasan/resitasi, dan (d) metode latihan/drill. Sedangkan pada pembelajaran non formal ketika kajian diterapkan metode bandongan/wetonan dan sorogan. Llangkah terapanan metode di atas belum diterapkan dengan sempurna, dan bervariasi. Langkah terapan dalam kegiatan pembelajaran, didominasi oleh penerapan metode ceramah dari 80 menit (60 menit penerapan metode ceramah, 20 menit penerapan metode lainnya yaitu metode tanya jawab dan penugasan), pada kegiatan pembelajaran di Madrasah Tsnawiyah, dan 90 menit (70 menit penerapan metode ceramah, 20 menit penerapan metode lainnya yaitu tanya jawab dan penugasan).

Sedangkan faktor pendukung penerapan metode adalah karena terbiasa menggunakan metode-metode tersebut, meskipun secara teoritis masih belum sempurna. Sementara faktor penghambat (a) kurang mengkaji literatur konsep pendidikan/pengajaran, (b) kurang trampil dalam penerapan metode, dan (c) tidak didukung dengan ketersediaan RPP, karena kurang trampil dalam merancangnya.

Soluasi mengatasi kesulitan, (a) ketersediaan buku-buku refrensi tentang penddikan/pembelajaran, (b) diperlukan latihan atau workhsop baik yang dilakukan pemerintah maupun oleh Kelompok Kerja Madrasah (KKM).

Paparan data ini sekalgus juga merupakan kesimpulan yang diperoleh dalam penelitian ini.

\section{DAFTAR PUSTAKA}

Hassan, Tarjamah Bulughul Maram Ibnu Hajar Al-'Asqalani : Terjemahan 
Beserta Keterangannya dengan Muqaddimah Ilmu Hadits dan Ushul Fiqih, Bandung : Diponegoro, 2006

Ahmad Tafsir, Ilmu Pendidikan dalam Perspektif Islam, Bandung : Remaja Rosdakarya, 1992

Abdorrakhman Ginting, Esensi Praktis Belajar \& Pembelajaran : Disiapkan untuk Pendidikan Profesi dan Sertifikasi Guru-Dosen, Bandung : Humaniora, 2007

Arifin Imron, Kepemimpinan Kyai : Kasus Pondok Pesantren Tebuireng, Malang : Kimasahada Press, 1993

A Sunyoto, Ajaran Tasawuf dan Pembinaan Sikap Hidup Santri Pesantren

Basyiruddin Usman, Metodology Pengajaran Agama Islam, Padang : ININ IB Press, 1999

Darwyn Syah, Perencanaan Sistem Pengajaran Pendidikan Agama Islam, Jakarta : Gaung Persada Press, 2007

Departemen Agama RI., Al-Qur'an dan Terjemahannya, Jakarta : Yayasan Penyelenggara PenterjemahAlQur'an Departemen Agama RI., 2004

Hadari Nawawi, Pendidikan dalam Islam, Surabaya : Al Ikhlas, 1993

Horikoshi, H., Kyai dan Perubahan Sosial, Jakarta : P3M, 1987

Kementerian Agama RI., Mushaf Al-Qur'an : Al-Qur'an Hafalan, Terjemah, Penjelasan Tematik Ayat, Jakarta : Yayasan Penyelenggara Penerjemah/Penafsiran Al-Qur'an Revisi Terjemah oleh Lajnah Pentashih Mushaf Al-Qur'an Kemneterian Agama Republik Indonesia, 2012

Lexy J. Moleong, Metodologi Penelitian Kualitatif, Bandung: PT Remaja Rosdakarya, 2010

Mastuhu, Dinamika Sistem Pendidikan Pesantren : Suatu Kajian Tentang Unsur dan Nilai Sistem Pendidikan Pesantren, Jakarta : IndonesiaNetherlands Cooperation in Islamic Studies/INIS, 1994
M. Atwi Suparman, Desain Instruksional Modern : Panduan Para Pengajar \& Inovator Pendidikan, Jakarta : Erlangga, 2012

Moh.Uzer Usman, Menjadi Guru Profesional, Edisi Kedua, Bandung : Remaja Rosdakarya, 1995

Nana Sudjana, Penilaian Hasil Proses Belajar Mengajar, Bandung : Remaja Rosdakarya, 2009

Nurul Zuhriah, Metodologi Penelitian Sosial dan Pendidikan Teori-Aplikasi, Jakarta : Bumi Aksara, 2009

Oemar Hamalik, Proses Belajar Mengajar, Jakarta : Bumi Aksara, 2001

Pupuh Fathurrohman dan M. Sobry Sutikno, Strategi Belajar Mengajar : Strategi Mewujudkan Pembelajaran Bermakna Melalui Penanaman Konsep Umum \& Konsep Islami, Bandung: Refika Aditama, 2007

Purwanto, Evaluasi Hasil Belajar, Yoyakarta : Pustaka Pelajar, 2008

Ramayulis, Metodologi Pendidikan Agama Islam, Edisi Revisi, Jakarta : Kalam Mulia, 2010

S. Eko Putro Widoyoko, Evaluasi Program Pembelajaran : Panduan Praktis bagi Pendidik dan Calon Pendidik, Yogyakarta : Pustaka Pelajar, 2009

Syaiful Sagala, Konsep dan Makna Pembelajaran : Untuk Membantu Memecahkan Problematika Belajar dan Mengajar, Bandung : Alfabeta, 2012

Sudirman.at.al., Ilmu Pendidikan, Bandung : Remaja Karya, 1987

Suharsimi Arikunto, Prosedur Penelitian Suatu Pendekatan Praktik, Edisi Revisi VI, Jakarta : Rineka Cipta, 2006

Sugiyono, Metode Penelitian Pendidikan Pendekatan Kuantitatif, Kualitatif dan R\&D Bandung:Alfabeta, 2010

Wina Sanjaya, Strategi Pembelajaran Berorientasi Standar Proses Pendidikan, Jakarta : Kencana Prenadamedia Group, 2006

Yusuf Tayar, dan Syaiful Anwar, Metodologi Pengajaran Agama dan Bahasa 
Arab, Jakarta : Rajaq Grafindo Persada, 1997

Zainal Aqib, Profesionalisme Guru dalam Pembelajaran, Surabaya : Insan Cendekia, 2002

Zamahsari Dhofir, , Tradisi Pesantren : Studi tentang Pandangan Hidup Kyai, Jakarta : LP3ES, 1984, h. 28

Z.A. Syis, et.al., Standarisasi Pengajaran Agama di Pondok Pesantren, Jakarta : Dirdjen Bimbaga Islam Depaertemen Agama Republik Indonesia, 1984 